\title{
Mardin Artuklu Üniversitesi Öğrencilerinin Antropometrik ve Sosyoekonomik Verilerinin Değerlendirilmesi ${ }^{1}$
}

\author{
Ayșe $\mathrm{ACAR}^{2}$, Ali BEDİR ${ }^{3}$
}

Atıf/C): Acar, Ayşe; Bedir, Ali, Mardin Artuklu Üniversitesi Öğrencilerinin Antropomedik ve Sosyoekonomik Verilerinin Değerlendirilmesi, Artuklu İnsan ve Toplum Bilim Dergisi 2020/5 (1), 1-14.

Öz

Antropometrik çalışmalarla toplumdaki bireylerin metrik verilerinin değerlendirilmesi ile topluma özgü standartların oluşturulmasını hedeflenmektedir. Çalışmanın amacı, genç nüfusu oluşturan üniversite öğrencilerinin demografik bilgileri ile birlikte sosyoekonomik yapılarının ortaya çıkarılması ve alınan antropometrik ölçülerle bireylerin antropometrik özelliklerini ortaya koymaktır. Mardin Artuklu Üniversitesi öğrencilerinden oluşan toplam 100 bireye (51 erkek, 49 kadın) demografik bilgilerini ve alışkanlıklarını içeren 15 adet sorudan oluşan anket, 17 adet uzunluk ölçümü, 14 adet genişlik ve çevre ölçümünden oluşan antropometrik ölçüm uygulanmıştır. Veriler bilgisayar ortamına aktarılarak istatistiksel analizleri SPSS programında hesaplanmıştır. Boy uzunlukları ortalamaları kadın bireylerde 159,01 cm, erkek bireylerde ise 175,02 cm'dir. Ağırlık ortalamaları kadın bireyler 55,03 kg, erkek bireyler 69,82 kg'dır. Beden kitle endisleri kadın (\%67,3) ve erkek $(\% 68,6)$ bireylerin ideal kilolu olduğu tespit edilmiştir. Erkek bireylerin \%5,9'unda obezite görülürken kadın bireylerde obeziteye rastlanmamıştır. Bütün antropometrik veriler değerlendirildiğinde erkeklerin ölçümlerde yüksek değerlerde olması cinsiyetler arası farklılıklardan dolayı olduğu tahmin edilmiştir. Genişletilmiş çalışmalarla veriler değerlendirilip toplumsal bir standart oluşturulmasına katkı sağlanabilir.

Anahtar Kelimeler: Antropometri, Sosyoekonomik Durum, Mardin, BKE.

\section{Evaluation of the Anthropometric and Socio-economic Data from Students of the Mardin Artuklu University}

Citation/C): Acar, Ayşe; Bedir, Ali, Evaluation of the Anthropometric and Socio-economic Data from Students of the Mardin Artuklu University, Artuklu Human and Social Science Journal 2020/5 (1), 1-14.

\section{Abstract}

With the anthropometric studies, it is aimed to establish standards specific to the society by evaluating the metric data of individuals in society. The aim of the study is to reveal the socioeconomic structure of the university students who constitute the young population together with the demographic information and to reveal the anthropometric characteristics of the individuals with the anthropometric measurements taken. A total of 100 individuals (51 male, 49 female) from Mardin Artuklu University students were interviewed with 15 questions including their demographic information and habits, anthropometric measurements were made of 17 length measurements, 14 width and circumference measurements. Data were transferred to the computer and statistical

${ }^{1}$ MAÜ-BAP-17-EF-12 nolu proje, Mardin Artuklu Üniversitesi BAP Koordinatörlüğü tarafindan desteklenmiștir. 2 Dr. Öğr. Üyesi, Mardin Artuklu Üniversitesi, Edebiyat Fakültesi, Antropoloji Bölümü, aysesolmaz01@gmail.com, ORCID: Orcid.org/0000-0002-1327-6378.

${ }^{3}$ Arş. Gör., Mardin Artuklu Üniversitesi, Edebiyat Fakültesi, Antropoloji Bölümü, alibedir@artuklu.edu.tr, ORCID: Orcid.org/0000-0003-4508-0676.

*Söz konusu makale 2020 yılı öncesi tamamlanan bir çalışma olması sebebiyle Etik Kurul iznine tabi tutulmamıștır.

Geliş/Received: 03.01.2020, Kabul/Accepted: 23.03.2020 
analyzes were calculated in the SPSS program. The average height of 159,01 cm in female, 175,02 $\mathrm{cm}$ in male. The weight averages of female individuals are $55.03 \mathrm{~kg}$ and male individuals are 69.82 $\mathrm{kg}$. Body mass indexes were found that female $(67.3 \%)$ and male $(68.6 \%)$ individuals were ideal weight. While obesity was seen in $5.9 \%$ of males, obesity was not observed in females. When all anthropometric data were evaluated, males had high values in measurements due to differences between genders. With extended studies, data can be evaluated and contributed to the establishment of a social standard.

Keywords: Anthropometry, Socioeconomic Status, Mardin, BMI.

\section{GíRiş}

İnsan vücut ölçülerinin belirlenmesi ve ölçümlerde belirlenen varyasyonlar toplumların antropometrik değerlerinin bilinmesi ile mümkündür (Akın, 2013). Antropometri yöntemi ile bireylerin boyutlarının belirlenmesi hedeflenmektedir (Akın, 2001). Toplumların antropometrik verilerin değerlendirilmesi sağlık, ergonomi, tasarım, gibi alanlarda o toplumun standartlarının oluşması, popülasyonlara özgü tasarımlara uygulanması toplumlararası farklılıkların en aza indirilmesine katkı sunmaktadır (Güleç ve ark., 2009). Toplumların sağlık ve sosyoekonomik durumunun belirlenmesi ile de toplumun genel durumu hakkında bilgi sahibi olunabilir. Toplumun genel yapısını, genetik, çevre, beslenme ve fiziksel aktiviteler gibi dış faktörler etkileyebilir (Akın, 2013). Antropometrik ölçümler, bireylerin beslenme ve sağlık durumları hakkında bilgi vermesi açısından önemlidir. $\mathrm{Bu}$ veriler toplumun fiziksel ve sosyokültürel özelliklerinin yansıması niteliğindedir. Ölçümler farklı yaş gruplarında değiş̧iklik gösterdiği gibi aynı yaş gruplarında ve hatta aynı yaş grubunda cinsiyetler arasında bile değişiklik gösterebilmektedir (Krishan, 2007). Genetik ve çevresel koşullar bireylerin büyüme ve gelişmesinde önemli katkılar sunmaktadır (Güleç ve ark., 2009; Demirsoy, 1994). Bireylerin vücut yapısı, fizyolojisi ve davranışları genetik yapı ve çevrenin etkisiyle ortaya çıkar. Büyüme ve gelişme ergenlik dönemine kadar kızlar ve erkeklerde benzer oranlarda seyrederken cinsiyetler arasında önemli bir farklılık görülmemektedir (Tanner ve ark, 1978). Ergenlik döneminin başlamasıyla cinsiyetler arasındaki farklılıklar oluşmaya başlamaktadır. Yetişkinlik döneminde ise cinsiyete özgü karakterler oluşmakta ve fiziksel gelişimler belirginleşmektedir.

Bir bütün olarak bireylerin değerlendirilmesinde sosyoekonomik yapının ve demografik özelliklerinin belirlenmesi, bireylerin gelişim ve büyüme aşamalarının anlaşılmasına katkı sunmaktadır (Güleç ve ark., 2009; Demirsoy, 1994). Sosyoekonomik düzeyin yükselmesi ile bireylerin yaşam kalitesini arttıracak beslenme ve sağlık koşullarına ulaşımı kolaylaşmaktadır. Böylece toplumdaki bireylerin genel sağlık durumları ve fiziksel gelişimleri olumlu yönde etkilenmektedir. Türkiye İstatistik Kurumu 31 Aralık 2018'de adrese dayalı kayılt sistemi sonuçlarına göre Türkiye'nin nüfusunu 82 milyon 3 bin 882 kişi olarak bildirilmiştir (TÜIK, 2019). Bu sonuçlara göre Mardin'de 20-24 yaş arası erkek 39175, kadın 37351, 25-29 yaş arası erkek 37054, kadın 36003'tür. İllere göre Mardin'de ortalama hane halkı büyüklüğü 5,2 kişi olarak tespit edilmiştir (TÜIK, 2017). Türkiye İstatistik Kurumundan (TÜIIK) alınan Ocak 2018 ürün fiyatlarına göre yapılan araştırmada çalışan tek kişinin yoksulluk sınırı 2 bin 661,57 TL olarak hesaplanmış, dört kişilik bir ailenin asgari geçim haddi ise 5 bin 414,49 Lira olarak belirlenmiştir.

Çalışmanın amacı, uygulanan anketle genç nüfusu oluşturan gruplardan biri olan üniversite öğrencilerinin sosyoekonomik ve demografik özelliklerinin belirlenmesi, alınan antropometrik ölçülerle aynı yaş grubundaki cinsiyetler arasındaki farkın ortaya konulması ve antropometrik özelliklerin sosyoekonomik yapı ile ilişkilerinin belirtilmesidir. 


\section{Materyal Metot}

Araştırmanın örneklem grubunu Mardin Artuklu Üniversitesi öğrencilerinden oluşan 51 erkek, 49 kadın birey toplam 100 adet birey temsil etmektedir. Araştırmaya katılan bireylerin yaşları 19 ile 31 yaş arasında tespit edilmiştir. Ölçümler iki kişi tarafından yapılmıştır. Katılımcılarla gönüllülük esasına dayalı olarak tek tek görüşme yapılarak 15 adet sorudan oluşan bir anket uygulanmıştır. Bu anket kapsamında bireylerin cinsiyet, yaş, anne eğitimi, anne mesleği, baba eğitimi, baba mesleği, kardeş sayısı, ailede çalışan sayısı, maaş, ailedeki obezite ve diyabet varlığı/yokluğu, sigara kullanımı, alkol kullanımı, spor yapma alışkanlığı ve fiziksel bir sorununun varlığı/yokluğuna dair bilgiler toplanmış ve anket formuna kaydedilmiştir (Ek 1). Ayrıca her bir bireyin boy uzunluğu ve kilo başta olmak üzere 21 adet antropometrik ölçüleri en az giysiyle bir çalışmacı tarafından alınmıştır (Ek 1).

Bireylerin boy uzunlukları Milli Eğitim Bakanlığı Ders Aletleri Yapım Merkezi tarafından imal edilmiş olan antropometri seti kapsamındaki antropometreyle, ağılıkları hassas tartı aletiyle, genişlik ölçüleri büyük ve küçük çap pergeliyle ve çevre ölçüleri esneme yapmayan mezura ile alınmıştır. Veriler bilgisayar ortamına aktarılarak istatistiksel analizleri SPSS 16 programında hesaplanmıştır.

Beden kitle endisi, vücut ağırlığının boy uzunluğunun karesine bölünmesiyle elde edilmektedir. Sonuç olarak elde edilen değer;

0-18,40: Zaylf

18,5-24,40: İdeal Kilo

25-29,90: Fazla Kilolu

30-34,90: Şişman (Obez) 1. Sınıf

35-44,90: Şişman (Obez) 2. Sınıf

45 ve üzeri: Aşırı şişman (Aşırı Obez) 3. Sınıf olarak değerlendirilmiş̧tir.

Demografik bilgiler, TÜiK’ten Mardin ili için elde edilen veriler ile öğrencilere uygulanan anket bilgilerinin karşılaştırılması sonucunda elde edilmiştir. Sosyoekonomik düzeyin belirlenmesi, Güneydoğu Anadolu Bölgesi içinde bulunan Mardin İli için, TUIKK verileri kullanılarak, aylık gelirlerin hane halkı sayısı bölünmesi sonucu, alt, orta ve yüksek sosyoekonomik düzey olarak belirlenmiştir.

\section{Bulgular}

Araştırmanın materyalini oluşturan 100 (51 erkek, 49 kadın) Mardin Artuklu Üniversitesi öğrencisine uygulanan anketle, bireylerin kardeş sayısı, anne babaların eğitim ve meslek bilgisi gibi demografik bulgular yardımıyla sosyoekonomik durumlarının tespiti yapılmaya çalışılmıştır. Her bireyin ortalama 6,33 kardeşe sahip olduğu tespit edilmiştir. Bireylerin ailelerinin eğitim ve mesleki bilgisi Tablo 1'de sunulmuştur. Buna göre katılımcıların anne eğitim düzeyi, 100 bireyde $\% 52$ oranında okuryazar olmadığı; baba eğitim düzeyi 100 bireyde $\% 48$ oranında ilkokul düzeyinde olduğu tespit edilmiştir. Anne eğitim düzeyinde ön lisans ve lisans eğitimi bulunmazken, baba eğitim düzeyinde bu oran sırasıyla $\% 1$ ve $\% 2$ oranında bulunmuştur. 
Mardin Artuklu Üniversitesi Öğrencilerinin Antropometrik ve Sosyoekonomik Verilerinin Dĕgerlendirilmesi

Tablo 1: Bireylerin Ailelerinin Ĕgitim Durumlarl

\begin{tabular}{|l|c|c|c|c|}
\cline { 2 - 5 } \multicolumn{1}{c|}{} & \multicolumn{2}{c|}{ Anne Eŭitim Düzeyi } & \multicolumn{2}{c|}{ Baba Eğitim Düzeyi } \\
\hline Okuryazar & $\mathrm{N}$ & $\%$ & $\mathrm{~N}$ & $\%$ \\
\hline Okuryazar değil & 1 & 1,0 & 3 & 3,0 \\
\hline Illkokul & 52 & 52,0 & 14 & 14,0 \\
\hline Ortaokul & 37 & 37,0 & 48 & 48,0 \\
\hline Lise & 7 & 7,0 & 15 & 15,0 \\
\hline Ön Lisans & 2 & 2,0 & 15 & 15,0 \\
\hline Lisans & 0 & 0 & 1 & 1,0 \\
\hline Yaşamıyor & 0 & 0 & 2 & 2,0 \\
\hline Toplam & 1 & 1,0 & 1,0 & 1,0 \\
\hline
\end{tabular}

Aile bireylerinin eğitim durumlarına göre 2018 yılı aylık kazanç durumları erkek ve kadın bireye göre şu şekilde sıralanmıştır (Tablo 2). Eğitim seviyeleri arttıkça aylık kazanç durumlarında artış gözlenmiştir. Cinsiyete göre bir karşılaştırma yapıldığında kadınların eğitim seviyelerinin artmasına rağmen erkeklerden daha az kazanca sahiptir.

Tablo 2: Aile Bireylerinin Eğitim Seviyelerine göre Aylık kazanç Durumları

\begin{tabular}{|l|c|c|}
\hline Eğitim Durumu & Erkek & Kadın \\
\hline İlkokul ve altı & 1594 & 1289 \\
\hline İlköğretim ve ortaokul & 1562 & 1318 \\
\hline Lise & 1755 & 1576 \\
\hline Meslek Lisesi & 2373 & 1851 \\
\hline Yüksekokul ve Üstü & 4296 & 3470 \\
\hline
\end{tabular}

Ankette "Ailede kaç kişi çalışıyor?” sorusuna 100 kişinin yanıtının ortalaması alındığında 1.7 kişi olarak bulunmuştur. Ailedeki toplam maaş ortalaması ise aile başına 2 bin 368 TL olarak hesaplanmıştır. Bireylerin ailelerinin aylık gelirleri ve hane halkı sayısına göre alt, orta ve yüksek sosyoekonomik gelir düzeyine göre incelediğimizde bireylerin \%89'unun alt gelir seviyesine ait olduğu görülmüştür (Tablo 3). 


\section{A. $A C A R-A . B E D I R$}

Tablo 3: Bireylerin ailelerinin ayllk gelir düzeyine göre dağgllımı

\begin{tabular}{|l|l|l|l|l|l|l|}
\hline & \multicolumn{2}{|c|}{ Kadın } & \multicolumn{2}{c|}{ Erkek } & \multicolumn{2}{c|}{ Toplam } \\
\hline Gelir Düzeyi & $\mathrm{N}$ & $\%$ & $\mathrm{~N}$ & $\%$ & $\mathrm{~N}$ & $\%$ \\
\hline $\begin{array}{l}\text { Alt Sosyoekonomik } \\
\text { Düzey }\end{array}$ & 42 & 85,7 & 47 & 92,2 & 89 & 89 \\
\hline $\begin{array}{l}\text { Orta Sosyoekonomik } \\
\text { Düzey }\end{array}$ & 4 & 8,2 & 2 & 3,9 & 6 & 6 \\
\hline $\begin{array}{l}\text { Yüksek Sosyoekonomik } \\
\text { Düzey }\end{array}$ & 3 & 6,1 & 2 & 3,9 & 5 & 5 \\
\hline Toplam & 49 & 100 & 51 & 100 & 100 & 100 \\
\hline
\end{tabular}

Ailedeki obezite varlı̆g sorusuna 4 birey var şeklinde açıklama getirmiştir. Bu bireylerden 3'ü annelerinin obez, 1'i babalarının obez olduğunu belirtmiştir. Katılımcılara sorulan bir diğer soru ailede diyabet hastalığının olup olmadığıdır. Cevap olarak 21 katılımcı ailesinde diyabet hastası bulunduğunu ifade etmiştir. İçlerinden 3 birey ailesinde 2 kişinin diyabet hastası olduğunu belirtmiştir. Ailesinde diyabet olduğunu belirtenlerin \%50'si annesinde, \%33,33'ü babasında, $\% 8,33$ 'ü kardeşinde ve \%8,33’ü kendisinin hasta olduğunu söylemiştir.

Bireylerin sigara alışkanlığının olup olmadığı sorusuna cevap olarak \%35'i sigara kullandığını, \%65'i sigara kullanmadığını belirtmiştir. Bu oranların cinsiyetler arasındaki kullanım oranına bakıldığında kullananların \% 68,57'si erkek, \%31,42'si kadın bireydir. Bireylerin alkol kullanım oranları toplamda $\% 9$ iken, alkol kullanımının erkek ve kadın oranına bakıldığında oranlar sirasıyla \%77,77 ve \%22,22'dir. Spor yapma sıklı̆̆1 sorusuna 44 katılımcı spor yaptıklarını belirtmişlerdir. Bireylerin ortalama spor yapma süreleri 35,11 dakika olarak hesaplanmıştır. Katılanların \%40’1 her gün 30 dakikasını spora ayırdığını, \%22.72'si haftada 2 veya 3 günün 30 dakikasını spora ayırdığını, \%29,54'ü ise haftada 1 gün 60 dakikasını spora ayırdığını belirtmiştir. $\mathrm{Bu}$ soruya cevap veren $\% 61,36$ oranındaki erkek bireyler yürüme ve futbol oynama gibi spor alanlarından bahsederken, $\% 38^{\prime} 63$ oranındaki kadın bireyler sadece yürüyüş yaptıklarını belirtmişlerdir. Fiziksel rahatsızlıklarının olup olmadığı sorusuna sadece 1 birey böbrek rahatsızlığının olduğunu ifade etmiştir.

Araştırma kapsamında bulunan kadın ve erkek katılımcılardan alınan antropometrik değişkenlerin istatistik ortalamaları Tablo 4'de sunulmaktadır. Katılımcı kadın ve erkek bireylerin yaş ortalamalarına bakıldığında üniversite öğrencileri olması nedeniyle ortalama aynı değerde sırasıyla 23,14 yaş ve 23,78 yaş olarak hesaplanmıştır. Ağırlık ortalaması erkek bireylerde $69,82 \mathrm{~kg}$, kadın bireylerde 55,03 kg olarak elde edilmiştir. Boy ortalaması erkek bireylerde 175,02 cm, kadın bireylerde $159,01 \mathrm{~cm}$ olarak ölçülmüştür. Boy, kilo ve yüzden alınan antropometrik ölçülerde görüldüğü gibi cinsiyet farklılıklarının ölçüm değerlerine yansıması önemli bir sonuç olarak değerlendirilebilir. 
Mardin Artuklu Üniversitesi Öğrencilerinin Antropometrik ve Sosyoekonomik Verilerinin Dĕgerlendirilmesi

Tablo 4: Erkek ve Kadın Bireylerin Baş ve Yüzden Alınan Antropometrik Verilerinin İstatistiki Analizi

\begin{tabular}{|c|c|c|c|c|c|c|}
\hline Cinsiyet & & $\mathbf{N}$ & Min. & Max. & Ort. & Std. S. \\
\hline \multirow[t]{10}{*}{ Erkek } & Yaş & 51 & 20 & 30 & 23,14 & 2,44 \\
\hline & Kilo (kg) & 51 & 54,00 & 113,00 & 69,82 & 10,78 \\
\hline & Boy $(\mathrm{cm})$ & 51 & 159,50 & 192,50 & 175,02 & 7,70 \\
\hline & Baş Uz. * & 51 & 16,80 & 20,00 & 18,39 & 0,81 \\
\hline & Baş Gen.* & 51 & 13,40 & 17,20 & 15,18 & 0,79 \\
\hline & Baş Çev. * & 51 & 52,00 & 60,00 & 56,15 & 1,93 \\
\hline & Üst Yüz Uz. * & 51 & 7,50 & 10,00 & 8,54 & 0,55 \\
\hline & Yüz Uz. * & 51 & 11,40 & 19,50 & 12,97 & 1,21 \\
\hline & Yüz Gen.* & 51 & 9,60 & 13,20 & 11,32 & 0,76 \\
\hline & Toplam & 51 & & & & \\
\hline \multirow[t]{10}{*}{ Kadın } & Yaş & 49 & 19 & 34 & 23,78 & 2,98 \\
\hline & Kilo (kg) & 49 & 42,00 & 70,00 & 55,03 & 6,87 \\
\hline & Boy (cm) & 49 & 148,00 & 171,00 & 159,01 & 5,00 \\
\hline & Baş Uz. * & 49 & 16,20 & 19,00 & 17,26 & 0,64 \\
\hline & Baş Gen.* & 49 & 12,40 & 15,40 & 14,26 & 0,62 \\
\hline & Baş Çev. * & 49 & 51,50 & 60,00 & 53,85 & 2,04 \\
\hline & Üst Yüz Uz. * & 49 & 7,00 & 9,00 & 8,03 & 0,45 \\
\hline & Yüz Uz. * & 49 & 10,20 & 19,30 & 12,13 & 1,69 \\
\hline & Yüz Gen.* & 49 & 9,00 & 12,00 & 10,34 & 0,53 \\
\hline & Toplam & 49 & & & & \\
\hline
\end{tabular}

Beden kitle endisleri kapsamında bireyler birlikte değerlendirildiğinde beden kitle endisi 22,33 ile ideal kiloda oldukları hesaplanmıştır. Erkeklerin BKE (Beden Kitle Endisi) 22,87, kadınların ise 21,77 olarak hesaplanmıştır. Tablo 5'de BKE (Beden Kitle Endisi) sonuçları erkek ve kadınlar ayrılarak verilmiştir. Buna göre ideal kiloda olan erkekler \%68,6 iken kadınlar \%67,3 olarak hesaplanmıştır. Kadınlarda şişman birey görülmezken erkeklerde \%5,9 oranında görülmüştür. BKE'sinde (Beden Kitle Endisi) zayıf olarak nitelendirilen kategoride kadınların oranı erkeklere göre daha fazladır. 
Tablo 5: Erkek ve Kadınların BKE Sonuçları

\begin{tabular}{|l|l|r|r|}
\hline Cinsiyet & \multicolumn{1}{|c|}{ Kategori } & \multicolumn{1}{c|}{ N } & \multicolumn{1}{c|}{$\%$} \\
\hline Erkek & Zayıf & 3 & 5,9 \\
\hline & İdeal & 35 & 68,6 \\
\hline & Fazla Kilolu & 10 & 19,6 \\
\hline & Şişman (Obez) 1 Sınıf & 3 & 5,9 \\
\hline Kadın & Toplam & 51 & 100,0 \\
\hline & Zayıf & 8 & 16,3 \\
\hline & İdeal & 33 & 67,3 \\
\hline & Fazla Kilolu & 8 & 16,3 \\
\hline & Toplam & 49 & 100,0 \\
\hline
\end{tabular}

Üst ekstremitelere ait olan el, kol uzunluk ve genişlik ölçüleri erkek ve kadın bireyler arasında görece farklılıklar olduğu görülmüştür (Tablo 6). Erkek bireylerden alınan tüm ölçülerde elde edilen değerlerin daha yüksek olduğu gözlenmiştir. Erkek bireylerdeki fiziksel üstünlüğün cinsiyetler arasındaki farklılık sonucu olabileceği şeklinde yorumlanabilir.

Tablo 6: Erkek ve Kadın Deneklerin El, Kol Uzunluk Ölçüleri(cm)

\begin{tabular}{|c|c|c|c|c|c|c|}
\hline Cinsiyet & & $\mathbf{N}$ & Min. & Max. & Ort. & Std. S. \\
\hline \multirow[t]{9}{*}{ Erkek } & Tüm Kol Uz.* & 51 & 67,50 & 88,50 & 77,85 & 4,10 \\
\hline & Ön Kol Uz.* & 51 & 23,50 & 51,50 & 27,99 & 4,95 \\
\hline & Üst Kol Uz.* & 51 & 26,50 & 42,00 & 36,49 & 2,64 \\
\hline & El Uz.* & 51 & 17,40 & 22,30 & 19,95 & 1,11 \\
\hline & El Gen.* & 51 & 7,20 & 88,00 & 9,86 & 11,16 \\
\hline & El Çev.* & 51 & 18,50 & 23,00 & 20,67 & 1,04 \\
\hline & El Bilek Gen.* & 51 & 5,00 & 6,30 & 5,66 &, 30 \\
\hline & Parmak Uz.* & 51 & 9,30 & 12,00 & 10,56 & ,67 \\
\hline & Toplam & 51 & & & & \\
\hline \multirow[t]{9}{*}{ Kadın } & Tüm Kol Uz.* & 49 & 64,00 & 76,50 & 69,16 & 2,64 \\
\hline & Ön Kol Uz.* & 49 & 22,00 & 41,50 & 24,29 & 2,77 \\
\hline & Üst Kol Uz.* & 49 & 27,50 & 39,00 & 32,46 & 2,09 \\
\hline & El Uz.* & 49 & 15,80 & 19,40 & 17,98 &, 76 \\
\hline & El Gen.* & 49 & 6,10 & 8,00 & 7,23 & ,39 \\
\hline & El Çev.* & 49 & 16,00 & 19,50 & 17,81 & 89 \\
\hline & El Bilek Gen.* & 49 & 4,20 & 5,80 & 4,91 & ,31 \\
\hline & Parmak Uz.* & 49 & 8,10 & 11,00 & 9,46 & ,63 \\
\hline & Toplam & 49 & & & & \\
\hline
\end{tabular}




\section{Değerlendirilmesi}

Alt ektremitelere ait olan çevre ve genişlik ölçülerinin ortalaması erkek ve kadın deneklerde Tablo 7'de gösterilmektedir. Üst ekstremitelerde görülen cinsiyetler arası farkl1lıklar alt ektsremitelerden alınan genişlik ve çevre ölçülerinde de gözlenmiştir. Birbirine en yakın değerler genişlik ölçülerinde kalça genişliğinde (Erkek: 30,68 cm, Kadın:29,70 cm) ve ayak genişliğinde (Erkek: 9,42 cm, Kadın: 8,18 cm) görülürken, uzunluk ölçülerinde oturma yüksekliğinde (Erkek: 57,99 cm, Kadın: 56,07 cm) olduğu saptanmıştır. Birbirine en uzak ölçüler çevre ölçülerinde görülmüş̧ür. Bu ölçüler bel çevresi erkeklerde ortalama $80,66 \mathrm{~cm}$, kadınlarda ortalama $67,78 \mathrm{~cm}$; karın çevresi erkeklerde ortalama $87,38 \mathrm{~cm}$, kadınlarda ortalama 75,88 cm; kalça çevresi erkeklerde ortalama $97,21 \mathrm{~cm}$, kadınlarda ortalama 93,03 cm'dir. Kadın bireylerde bölgesel yağlanma oranının fazla olması beklentisinin aksine erkek bireylerde bel, karın ve kalça çevrelerinde yağlanmanın kadınlara oranla daha fazla olduğu görülmüştür.

Tablo 7: Erkek ve Kadın Alt Ekstremite Genişlik ve Çevre Ölçüleri (mm)

\begin{tabular}{|c|c|c|c|c|c|c|}
\hline Cinsiyet & & $\mathbf{N}$ & Min. & Max. & Ort. & Std. S. \\
\hline \multirow[t]{15}{*}{ Erkek } & Bel Çev. & 51 & 67,00 & 116,00 & 80,66 & 9,61 \\
\hline & Basen Gen. & 51 & 25,00 & 35,50 & 28,14 & 1,76 \\
\hline & Karın Çev. & 51 & 76,00 & 120,00 & 87,38 & 8,46 \\
\hline & Kalça Çev. & 51 & 81,50 & 150,00 & 97,21 & 9,89 \\
\hline & Kalça Gen. & 51 & 23,20 & 40,30 & 30,68 & 2,78 \\
\hline & OturmaYük. & 51 & 49,00 & 62,00 & 57,99 & 2,63 \\
\hline & Diz Yük & 51 & 42,00 & 57,00 & 50,00 & 3,20 \\
\hline & Kalça Diz Uz. & 51 & 41,50 & 67,00 & 56,06 & 4,32 \\
\hline & Alt Bacak Uz. & 51 & 35,00 & 56,00 & 42,15 & 3,91 \\
\hline & Ayak Uz. & 51 & 22,60 & 29,20 & 25,95 & 1,33 \\
\hline & Ayak Gen. & 51 & 8,00 & 10,30 & 9,42 &, 56 \\
\hline & Ayak Bilek Gen. & 51 & 5,00 & 7,80 & 6,49 & 67 \\
\hline & Üst Bacak Çev. & 51 & 40,50 & 63,00 & 48,97 & 4,94 \\
\hline & Alt Bacak Çev. & 51 & 27,50 & 43,00 & 35,36 & 3,39 \\
\hline & Toplam & 51 & & & & \\
\hline \multirow[t]{15}{*}{ Kadın } & Bel Çev. & 49 & 57,00 & 85,00 & 67,78 & 6,21 \\
\hline & Basen Gen. & 49 & 19,00 & 88,00 & 26,55 & 9,26 \\
\hline & Karın Çev. & 49 & 60,00 & 95,00 & 75,85 & 8,10 \\
\hline & Kalça Çev. & 49 & 23,40 & 107,00 & 93,03 & 11,80 \\
\hline & Kalça Gen. & 49 & 24,00 & 35,00 & 29,70 & 2,44 \\
\hline & OturmaYük. & 49 & 44,50 & 61,00 & 56,07 & 4,28 \\
\hline & Diz Yük & 49 & 36,00 & 50,00 & 44,65 & 2,68 \\
\hline & Kalça Diz Uz. & 49 & 34,50 & 58,00 & 51,84 & 4,09 \\
\hline & Alt Bacak Uz. & 49 & 33,00 & 43,00 & 37,88 & 1,86 \\
\hline & Ayak Uz. & 49 & 21,30 & 26,00 & 23,04 & ,88 \\
\hline & Ayak Gen. & 49 & 7,20 & 9,30 & 8,18 & ,47 \\
\hline & Ayak Bilek Gen. & 49 & 4,90 & 7,20 & 5,98 & ,51 \\
\hline & Üst Bacak Çev. & 49 & 41,00 & 60,00 & 51,03 & 4,70 \\
\hline & Alt Bacak Çev. & 49 & 29,00 & 38,00 & 33,64 & 2,23 \\
\hline & Toplam & 49 & & & & \\
\hline
\end{tabular}




\section{A. $A C A R-A . B E D I R$}

\section{Tartışma}

Antropometrik alan araştırmaları bireyler ve ülkeler için önemli bir yere sahiptir (Koca Özer ve ark., 2003; Özgün Başıüyük ve ark, 2017). Bireylerden alınan ölçümlerle farklı toplumlar arasında karşılaştırma yapılarak bir veri tabanının yanı sıra benzerlikler ve farklılıklar ortaya konabilir. Antropometrik veriler bu özelliği ile toplumların standartlarının oluşturulması, büyüme ve gelişmenin izlenmesi açısından önem arz etmektedir.

Toplumların antropometrik değerlerinin oluşmasında çevresel ve genetik faktörlerin katkısı büyüktür (Güleç ve ark. 2009). Genetik ve çevresel faktörlerin yanında toplumların sosyoekonomik durumlarının da birlikte değerlendirilmesi toplumları ergonomik açıdan değerlendirmede yararlı olacaktır. Ailelerin eğitim durumları sosyoekonomik yapıyı etkileyen nedenlerden biri olduğu için, anket çalışmasında bireylere ailelerinin eğitim durumları sorulmuştur. Bu çalışmada, değerlendirilen ailelerin eğitim durumları 2005 yılı Türkiye sonuçları ile karşılaştırıldığında erkek (\%14) ve kadın (\%52) oranları Türkiye ortalamasının çok üstünde bulunmuştur. Çalışmada ailelerin eğitim alma oranlarının Türkiye ortalamasına göre daha düşük oranda çıkmasının sebebi, çalışmaya katılan öğrencilerin Mardin ve çevre illerden gelen bireyler olmasından kaynaklandığı tahminini ortaya çıkarmıştır (Üçeçam Karagel, 2009). Güleç ve arkadaşlarının 2005 yılı Türkiye genelinde yapılan ve antropometrik verilere dayanan makale çalışmalarında erkek ve kadın okuma yazma bilmeyen bireylerin oranları sırasıyla \%3,6 ve \%21,5’tir (Güleç ve ark., 2009).

Çalışmada bireylerin sosyoekonomik düzeyi, Türkiye İstatistik Kurumundan (TÜiK) alınan Ocak 2018 fiyatlarına göre yapılan araştırmada çalışan tek kişinin yoksulluk sınırı 2 bin 661,57 TL olarak hesaplanmış, dört kişilik bir ailenin asgari geçim haddi ise 5 bin 414,49 TL olarak belirlenmiştir. Her bireyin ailesinin ortalama aylık geliri 2 bin 368 TL olarak hesaplanmıştır. Sosyoekonomik düzey ile kardeş sayısının, dolayısıyla aile büyüklüğü arasında ters bir orantı vardır (Tanner, 1988). Gelişmiş ülkelerden az gelişmiş ülkelere doğru gidildikçe çocuk sayısında bir artış gözlenmektedir. Çalışmadaki ortalama kardeş sayısı 6,33 kişi olan minimum aile birey sayısı 8 olarak düşünüldüğünde, aylık kazanç Türkiye ortalamasının altında kalmaktadır.

Günümüzde birçok ülkede sağlık sorunlarından biri olarak kabul edilen obezitenin görülme sıklığı, erken yaşlardan itibaren artış yönünde eğilim göstermektedir (Çalışkan ve Atak, 2013). Türkiye İstatistik Kurumu, 31 Mayıs 2017 de Türkiye sağlık araştırması (2016) raporunda 15 yaş ve üstü obez bireylerin oranı 2014 yılında \%19,9 iken, 2016 yılında $\% 19,6$ olarak açıklamıştır (TUíK, 2017). Cinsiyetler arasında inceleme yapıldığında 2016 yılında kadınların \%23,9'unun obez, \%30,1'inin obez öncesi olarak nitelendirilen fazla kilolu bireylerden oluştuğu gözlenmiştir. Erkeklerde bu oranlar sırasıyla \%15,2 ve \%38,6 olduğu belirtilmiştir. Bu çalışmaya katılan erkek bireylerde obezite görülme oranı $\% 5,8$ iken kadın bireylerde obeziteye rastlanmamıştır.

Katılımcılara sorulan bir diğer soru ailede diyabet hastalığının varlığıdır. Bu soruya 21 kişi, ailesinde diyabet hastalığının olduğu şeklinde cevaplamıştır. İçlerinden 3 birey ailesinde, 2 kişi kendisinde diyabet hastalığı olduğunu belirtmiş̧tir. Ailesinde diyabet hastalığı olduğunu belirtenlerin $\% 50$ 'si annesinde, $\% 33,33$ 'ü babasında, $\% 8,33$ 'ü kardeşinde ve $\% 8,33$ 'ü kendisinin diyabet hastası belirtmiştir. Ülkemizde bölgesel diyabet prevalansı \%14.5 ile en az Kuzey Anadolu'da, \%18.2 ile en fazla Kuzey Anadolu'dadır (Bakan ve ark., 2017).

Türkiye İstatistik Kurumunun 2016 yılı sağlık raporunda her gün tütün kullanan bireylerin oranı 2014 yılında \%27,3 iken, 2016 yılında \%26,5 olarak belirtilmiştir (TUIK, 2017). Bu oran 2016 yılında erkeklerde $\% 40,1$, kadınlarda $\% 13,3$ oranında olmuştur. Bireylerin kendisinin sigara alışkanlığının olup olmadığı sorusuna cevap olarak \%35'i sigara kullandığını, \%65'i ise sigara kullanmadığını belirtmiştir. $\mathrm{Bu}$ oranlarda erkek kadın arasındaki kullanıma bakıldığında kullananların \%68,57'si erkek, \%31,42'si kadın bireydir. Bireylerin alkol kullanım oranları 
toplamda \%9 oranında iken, alkol kullanımının erkek ve kadın oranına bakıldığında oran sırasıyla $\% 77,77$ ve \%22,22'dir. Türkiye İstatistik Kurumunun 2016 yılı verilerine göre karşılaştırıldığında çalışmaya katılan bireylerde yüksek oranda sigara kullanımı olduğu tespit edilmiştir. Üniversite öğrencileri arasında yapılan bir başka çalışmada sigara içme oranı $\% 48,8$ olarak bulunmuştur (Orak ve ark., 2004).

İnsan yaşamı için önemli faaliyetlerden olan sporun üniversite öğrencileri arasında yapılma oranına bakıldığında katılımcıların \%40'1 spor aktivitelerine katıldıklarını belirtmiştir. Profesyonel olarak bir spor dalı ile uğraşmadıklarını belirten öğrenciler, sosyal etkinlik olarak spora zaman ayırdıklarını, bu spor zamanlarını da yürüme ve futbol oynayarak geçirdiklerini ifade etmişlerdir. Öğrencilerin \%40'ı her gün 30 dakikasını spora ayırdığını, \%22.72'si haftada 2 veya 3 günün 30 dakikasını spora ayırdığını, \%29,54'ü ise haftada 1 gün 60 dakikasını spora ayırdığını belirtmiştir. Üniversite öğrencileri arasında yapılan bir çalışmada hayatlarında $\% 42,28$ oranında spora yer verdiklerini belirtmişlerdir (Orak ve ark., 2004).

Mardin Artuklu Üniversitesi öğrencileri üzerinden yapılan antropometrik verilerin sonuçları önceki yıllarda yapılan çalışmalarla karşılaştırıldığında popülasyonun farklı antropometrik değerlere ulaştığ1 görülmüştür. Çiner (1960), kadınların boy ortalamasını 155,43 cm olarak hesaplanmıştır. Güleç ve arkadaşlarının (2009), 2005 yılı Türkiye genelinde yaptıkları antropometrik verilere dayanan çalışmasında, boy ortalaması erkeklerde $168,88 \mathrm{~cm}$, kadınlarda ise $155,3 \mathrm{~cm}$ olarak hesaplanmıştır. Çalışmadaki boy ortalaması değerleri önceki çalışmalarla karşılaştırıldığında hem erkek bireylerde $(6,14 \mathrm{~cm})$, hem de kadın bireylerde $(3,71 \mathrm{~cm})$ fark olduğu saptanmıştır. Önceki çalışma gruplarının toplumun genel popülasyonu üzerinden yapılması bu çalışma grubunun ise yaş aralığının genç olması sonuçlardaki farkın oluşmasına neden olan faktörlerden olduğu tahmin edilmiştir.

Beden kitle endisi, şişmanlık ve vücuttaki yağ miktarı hakkında genel bilgiler vermektedir (Akın, 2001). Hesaplanan değerler, toplum sağlığını genel anlamda değerlendirmemize imkân sağlamaktadır. Beden kitle endisi ile kilo dağılımları benzer çalışmalarla karşılaştırılması sonucunda yaklaşı değerler tespit edilmiştir. İstanbul'daki vakıf üniversitelerindeki öğrenciler üzerinden yapılan çalışmada normal kiloda olanların yüzdesi \%68,4 olarak bulunmuştur (Kadıoğlu ve Ergün, 2015). Çalışmada ise ideal kilodaki erkekler \%68,6, kadınlar ise \%67,3 olarak hesaplanmıştır. 2005 yılındaki Türkiye antropometri araştırmasında ilerleyen yaşla birlikte erkekte ve kadınlarda BKE değerlerinde yüksek oranlar görülmüştür (Güleç ve ark., 2009). Yaptığımız araştırmanın yaş aralığı genç bireyleri ifade etmektedir. Ergün ve Erten'in (2004) öğrenciler üzerinde yapmış oldukları çalışmada ise BKE'de zayıf olarak sınıflandırılan erkek ve kadın bireylerde oranlar, çalışmadaki verilerle benzerlik taşımaktadır. Yücel ve arkadaşlarının (2017), 18-22 yaş arasındaki öğrenciler arasındaki antropometrik değerlendirmesinde BKE ortalama değerleri (Kadın: 22,08, Erkek:31,5) çalışmadaki ortalama değerleri (Kadın: 21,77, Erkek: 22,87) ile az da olsa farklılık taşımaktadır. Sivas ili farklı sosyoekonomik düzeye sahip bireyler üzerinden yapılan antropometrik değerlendirmelerde BKE değeri, kadın ve erkekler arasında karşılaştırıldığında 20-35 yaş arasında erkeklerin, kadınlara oranla daha büyük değerlere sahip olduğunu görülmüştür (Özgün Başıüyük, 2007).

Çalışmada baş üzerinden alınan antropometrik ölçümlerde, cinsiyetler arasında istatistiksel olarak anlamlı farklılık olduğu ve bu ölçümlerin ortalamasının erkek bireylerde daha yüksek olduğu tespit edilmiştir. Fazlıŏulları'nın üniversite öğrencileri üzerinde yaptığı çalışma ile karşılaştırıldığında az da olsa farklı değerler gözlenmiştir (Fazlıoğulları ve ark., 2016). Bu farklılığın ölçümü yapılan bireylerin farklı genetik ve çevresel koşullara sahip olması sebebiyle olduğu düşünülmektedir. 


\section{A. $A C A R-A . B E D I R$}

18-21 yaş üniversite öğrencilerinin antropometrik el ölçümü üzerinde yapılan çalışmada, tüm kol uzunluğu, el uzunluğu, el genişliği, el çevresi ve el bilek genişliği verileri ile karşılaştırma yapılmıştır (Taştan, 2018). Kadın bireyler arasında tüm ölçülerde benzerlik gözlenirken, erkek bireylerde el uzunluğu ve el genişliği değerlerinde farklılık gözlenmiştir. Çalışmamızda erkek bireylerin el uzunluk ortalaması 19,95 cm iken Taştan'ın yaptığı çalışmada $18,6 \mathrm{~cm}$ ve el genişliği erkek bireylerin ortalaması $9,86 \mathrm{~cm}$, karşılaştırılan çalışmada $8,4 \mathrm{~cm}$ olarak bulunmuştur.

18-22 yaş öğrenciler arasında alt ekstremite çevre ve uzunluk ölçülerinden bel çevresi, kalça çevresi, uyluk çevresi, ayak uzunluğu ve ayak genişliği çalışmamız ile karşılaştırıldığında çevre ölçülerinde erkek ve kadın bireyler arasında az da olsa bir farklılık gözlenmiştir (Yücel ve ark., 2017). Uzunluk ölçülerinde hemen hemen aynı değerlere rastlanmıştır. Sıra tasarımı için öğrenciler üzerinden yapılan antropometrik ölçümlerde otururken diz yüksekliği ölçümünün karşılaştırılmasında erkekler ve kadınlar arasında farklılık gözlenmiştir (Akın ve ark., 2014). Bu farklılığın öğrencilerin boy uzunluk ortalamaları ile karşıllaştırıldığında Akın ve arkadaşlarının yapmış olduğu çalışmada erkek ve kadın bireylerin ortalamalarının daha uzun olduğu görülmüştür.

\section{SONUÇ}

Çalışmada örneklem grubunu oluşturan üniversite öğrencilerine anket ve antropometrik ölçümler uygulanmıştır. Her toplumun kendine özgü antropometrik boyutları olması sebebiyle farklı ülkelerdeki standartların ülkemiz bireylerine uygulanması sonucunda bazı uyumsuzluklarla karşılaşılabilir. Çalışmanın sonuçlarını şu şekilde sıralayabiliriz;

- Katılımcıların anne eğitim düzeyi \%52 oranında okuryazar olmadığı, baba eğitim düzeyi $\% 48$ oranda ilkokul seviyesinde olduğu tespit edilmiştir. Çalışmaya katılan öğrencilerin Mardin ve çevre illerden geldikleri düşünüldüğünde ailelerin eğitim alma oranlarının Türkiye ortalamasına göre daha düşük oranda olması beklenilen bir sonuçtur.

- Katılımcıların sosyoekonomik düzeyinin sinıflaması sonucunda \%89 oranında alt sosyoekonomik gelir seviyesinde olduğu tespit edilmiştir. Güneydoğu Anadolu bölgesinin Türkiye ortalamasının altında gelir seviyesinde olması sonucu, bireylerin ailelerinin ekonomik düzeylerine bu durumun yansıması beklenen bir veri olarak karşımıza çıkmıştır.

- Katılımcıların sigara, alkol kullanım oranlarının 2016 TÜiK verilerine göre daha yüksek oranda olduğu tespit edilmiştir.

- Sosyal etkinlik planları arasında spora ayrılan zamanın genç bireylerden oluşan katılımcılardaki oranına bakıldığında bu oran günlük ayrılması gereken süreden daha az olduğu tespit edilmiştir.

- Katılımcılar, ağırlık açısından değerlendirildiğinde, erkek bireylerin kadın bireylerden daha ağır olduğu saptanmıştır. Genç erkek bireylerdeki kas ve kemik yoğunluğunun fazla olması sebebiyle, erkeklerin kadın bireylere göre ağırlığının daha yüksek olması beklenen bir sonuç olarak karşımıza çıkmıştır. Ayrıca tek taraflı beslenme ile vücuttaki yağ oranını artmaktadır.

- Boy uzunluğu farkı, cinsiyetler arasında değerlendirildiğinde belirgin farklar göze çarpmaktadır. Kadın ve erkek bireyler arasında $16,01 \mathrm{~cm}$ 'lik farkın topluma özgü bir fark olduğu tahmin edilmiştir.

- Beden kitle endis değeri, erkek ve kadınlar arasında ortalama değerlerde hesaplanmıştır. Katılımcıların yaş aralığı 20-24 yaş arasında yoğunluk gösterdiği için farklı yaş aralıklarında cinsiyetler arasındaki BKE değeri farkları gözlenememiştir.

- Üst ekstremitelere ait olan el, kol uzunluk ve genişlik ölçüleri erkek ve kadın bireyler arasında görece farklılıklar olduğu gözlenmiştir. Bu fark, erkek bireylerdeki fiziksel üstünlüğün sonucu olabileceği şeklinde yorumlanabilir.

- Üst ekstremitelerde görülen cinsiyetler arası farklılıklar alt ektsremitelerden alınan genişlik ve çevre ölçülerinde de gözlenmiştir. Birbirine en yakın değerler genişlik ölçülerinde kalça 
genişliğinde ve ayak genişliğinde görülürken, uzunluk ölçülerinde oturma yüksekliğinde olduğu saptanmıştır. Birbirine en uzak ölçüler bel çevresi, karın çevresi, kalça çevresi'dir. Kadın bireylerde bölgesel yağlanma oranının fazla olması beklentisinin aksine erkek bireylerde bel, karın ve kalça çevrelerinde yağlanmanın kadınlara oranla daha fazla olduğu görülmüştür.

Genel olarak değerlendirdiğimizde antropometri tekniği ile yapılan çalışmanın, ülkenin genç insanlarının bulunduğu üniversitelerdeki öğrencilerin yaşam kalitesini arttırmasına yönelik etkisinden söz edilebilir. Çalışmanın benzer yaş grupları ile karşılaştırılması, genç bireyler için tasarlanabilecek olan ergonomik tasarımlar için veri oluşturması açısından da önemlidir. Antropometrik değerlerin bölge insanının morfolojik yapısı, sağlık, beslenme, ailelerinin eğitim durumları hakkında genel bilgiler sunmaktadır. Bireylerin sosyoekonomik yapılarının belirlenmesinin yanı sıra alışkanlıklarının ve sosyal etkinlik planlarında sporun yerinin anlaşılması, sağlık durumunun daha iyi değerlendirilmesini sağlayacaktır. Toplumun genç bireylerine yönelik yapılan projelerde, buna benzer çalışmaların katkı sunacağı düşünülmektedir.

\section{KAYNAKÇA}

Akın, G. (2001). Antropometri ve Ergonomi. Ankara: İnkansa Ofset Matbaacilık.

Akın, G. (2013). Yaşam Kalitesinin Artırılmasında Antropometrinin Önemi. Ankara Üniversitesi DTCF Antropoloji Dergisi, S. 26, s. 1-18.

Akın, G. - Gültekin, T. - Bektaş, Y. - Önal, S.- Tuncel, E. (2014). Üniversite Öğrencileri İçin Sıra Tasarımı. Ankara Üniversitesi DTCF Antropoloji Dergisi, S. 54(1), s. 269-286.

Bakan, G. - Azak, A. - Özdemir, Ü. (2017). Diyabet ve Sosyo-Kültürel Yaklaşım. Kesit Akademi Dergisi, S. 12, s. 180-195.

Çalışkan, A. - Atak, N. (2013). Çocukluk Çağı Obezitesine Genel Bakış. TAF Preventive Medicine Bulletin, S. 12(5), s. 571-582.

Çiner, R. (1960). Türkiye Kadınlarının Antropolojisi. Ankara Üniversitesi Dil ve TarihCoğrafya Fakültesi Dergisi, S. 18(3-4), s. 161-200.

Demirsoy, A. (1994). Kalttım ve Evrim. Ankara: Meteksan Anonim Şirketi.

Ergün, A. - Erten, S. F. (2004). Öğrencilerde Vücut Kitle İndeksi ve Bel Çevresi Değerlerinin İncelenmesi. Ankara Üniversitesi Tip Fakültesi Mecmuası, C. 57, S. 2, s. 57-61.

Fazlioğlu, Z. - Dedeoğlu, H. - Bakan, T. - Şanda, F. B. - Özbal, F. S. - Tuncer, K. - Aksoy, M. E. - Günaydin, S. M. - Ekinci, B. - Ünsaçan, M. E. (2016). Tıp Fakültesi Öğrencilerinin Kraniofasial Ölçümlerinin Antropometrik Değerlendirmesi. Genel Tip Dergisi, S. 26, s. 16-19.

Güleç, E. - Akin, G. - Sağir, M. - Koca Özer, B. - Gültekin, T. - Bektaş, Y. (2009). Anadolu İnsanının Antropometrik Boyutları: 2005 Yılı Türkiye Antropometri Anketi Genel Sonuçları. Ankara Üniversitesi Dil Tarih Coğrafya Fakültesi Dergisi, S. 49(2), s. 187-201.

Kadığlu, M. - Ergün, A. (2015). Üniversite Öğrencilerinin Yeme Tutumu, Öz-Etkinlik ve Etkileyen Faktörler. MÜSBED, S. 5(2), s. 96-104.

Koca Özer, B. - Gültekin, T. - Yılmaz, E. - Güleç, E. - Akın, G. (2003). Emniyet Müdürlüğü Personelinin Antropometrik Karakterleri; Ergonomik Yaklaşımlar. Polis Bilimleri Dergisi, S. 5(34), s. 39-46.

Krıshan, K. (2007). Anthropometry in Forensic Medicine and Forensic Science-Forensic Anthropometry. The Internet Journal of Forensic Science, C. 2, S. 1, s. 1-8.

Orak, S. - Özen, T. - Orak, M. E. (2004). Süleyman Demirel Üniversitesi Öğrencilerinin Sigara, Alkol Alışanlıkları ve Sosyokültürel Özelliklerinin İncelenmesi. S.D.Ü. Tip Fak. Dergisi, 11(3), s. 1-7. 


\section{A. $A C A R-A . B E D I R$}

Özgün Başıüyük, G. (2007). Sivas Illi Farkll Sosyoekonomik Düzeye Sahip Yetişkin Bireylerde Bazı Antropolojik Özeliklerin Tespiti ve Değerlendirilmesi. Doktora Tezi, Ankara: Ankara Üniversitesi Sosyal Bilimler Enstitüsü.

Özgün Başibüyük, G. - Acar, S. - Doğan, M. (2017). Antropometrik Ölçümlerin Polis Adaylarının Silah Atış Performansları Üstünde Etkisi. Hitit Üniversitesi Sosyal Bilimler Enstitüsü Dergisi, C. 10, S. 2, s. 757-774.

Tanner, J. M. (1988). Human Growth and Constitution, Human Biology. An Introduction to Human Evolution, Variation, Growth, and Adaptability (Eds. Harrison G.A. - Tanner J.M. Pilbeam D.R. - Baker P.T.). Oxford: Oxford University Press, s. 337-435.

Tanner, J. M. - Hıernaux, J. - Jarman, S. (1978). Büyüme ve Beden Yapısı Üzerindeki Antropometrik İncelemeler. (Çev: Armağan Saatçioğlu), Antropoloji, S. 8, s. 92-111.

Taştan, A. (2018). 18-21 Yaş Aralı̆gndaki Üniversite Öğrencilerinin Antropometrik El Ölçümleri ve Bu Ölçümlerin Belli Vücut Ölçüleriyle Karşılaştırılması. İstanbul: İstanbul Üniversitesi, Cerrahpaşa Tıp Fakültesi Anatomi Anabilim Dalı, Uzmanlık Tezi.

Üçeçam Karagel, D. (2009). Doğu Anadolu Kırsalında Kadın Nüfusun Okur-Yazarlığı. Doğu Anadolu Araştırmaları, C. 8, S. 1, s. 14-23.

Yücel, A. H. - Özandaç Polat, S. - Kabakçı, A. G. (2017). 18-22 Yaş Arası, Çukurova Üniversitesi Öğrencilerinin Cinsiyete Göre Alt Ekstremite Antropometrik Ölçümlerinin İncelenmesi. Harran Üniversitesi Tip Fakültesi Dergisi, C.14, S. 1, s. 1-11.

Url 1: www.tuik.gov.tr, https://biruni.tuik.gov.tr/medas/?kn=95\&locale=tr (Erişim Tarihi: 15.11.2019). 
Mardin Artuklu Üniversitesi Öğrencilerinin Antropometrik ve Sosyoekonomik Verilerinin Değerlendirilmesi

Ek 1: Çalışma İ̧̧in Öğrencilere Uygulanan Anket ve Antropometrik Ölçümler

\begin{tabular}{|l|l|l|}
\hline Sıra & Yüz Genişliği & \\
\hline Cinsiyet & Bel Çevresi & \\
\hline Yaş & Basen Genişliği & \\
\hline Anne Ĕ̆itimi & Karın Çevresi & \\
\hline Anne Mesleği & Kalça Çevresi & \\
\hline Baba Eğitimi & Kalça Genişliği & \\
\hline Baba Mesleği & Oturma Yüksekliği & \\
\hline Ailedeki Kardeş Sayısı & Otururken Diz Yüksekliği & \\
\hline Ailede Çalışan Kişi Sayısı & Otururken Kalça Diz Uzunluğu & \\
\hline Ailede Çalışan Bireylerin Maaş Toplamı & Tüm Kol Uzunluğu & \\
\hline Ailede Obezite Varlı̆̆ı & Ön Kol Uzunluğu & \\
\hline Ailede Diyabet Hastalığı Varlığı & Üst Kol Uzunluğu & \\
\hline Sigara Kullanımı & El uzunluğu & \\
\hline Alkol Kullanımı & El genişliği & \\
\hline Spor Yapma Siklı̆̆ı & El Çevresi & \\
\hline Fiziksel Rahatsızlıkların varsa durumu & El Parmak Uzunluğu & \\
\hline Kilo & El Bilek Genişliği & \\
\hline Boy & Alt Bacak Uzunluğu & \\
\hline Baş Uzunluğu & Ayak Uzunluğu & \\
\hline Baş Genişliği & Ayak Genişliği & \\
\hline Baş Çevresi & Ayak Bileği Genişliği & \\
\hline Üst Yüz Uzunluğu & Üst Bacak Çevresi & \\
\hline Yüz Uzunluğu & Alt Bacak Çevresi & \\
\hline
\end{tabular}

